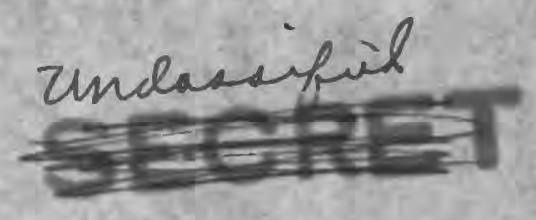

T IS DO 'MENT CO ST $R S 0=13$
NO 6 _ _ $0: 8$

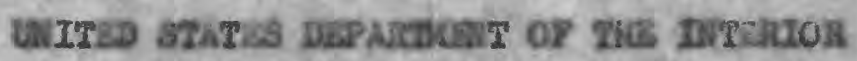

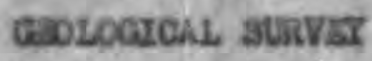

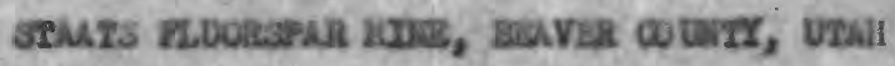

wasoundas genst

Dy Dorald C. Whate

unclacifind 
Introduotion ....................................................... 1

Locetion and provlous wort ...................................... 2

Hetary and prodvotion ........................................ 2

Q Qoologg ........................................................... 3

torkinga .......................................................4 4

Radtosetivity ................................................. $s$

Mlesturnanate at the outorop ..................................... s

Sampla in the vielnity of the staute Ruarspar alne .......... 6

Other 1gneous bedles ............................................... 7

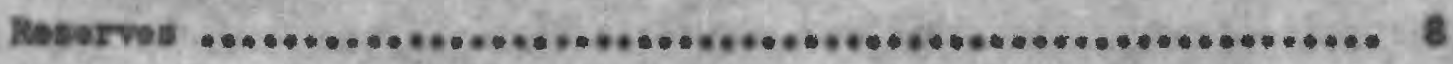

Sumery and reeomandatione ....................................... 9

hppend1x ....................................................... 12

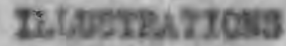

Pigurs 1. Skateh aep of Ceology in vloinity of nain shart Dtaste ine, Bosyer oounty, Dteh. 


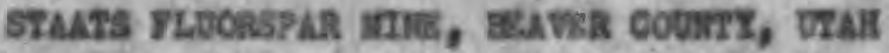

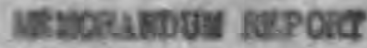

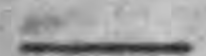

By Deasid 0. lyant

\section{InrroDoct ICA}

\section{Leentlog and inrevilous zork}

The stante nuorepar atne in in the soctbarn part of the Feh Weh wountains, sbout 35 allos by graded road northwest frea Lind, Dtah

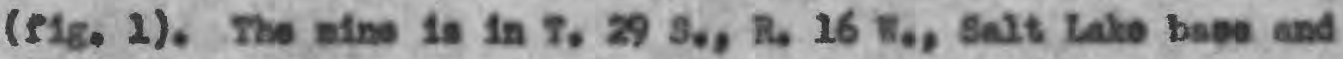
neridian, Boever County, Wtah in what in sonebinos ealled the 7 ine Grovs alning alatelot $\mathcal{L}$.

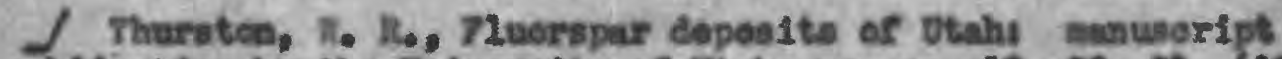
for poblteation by the thiveraity of vtahy $=\mathrm{ss}$. pp. 19, 20, 22, (1946).

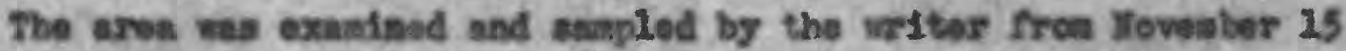
to 20, 1947. He. A. 8. Granger of the Goologieal Survey's Balt lake C1ty regional offleo seted ss gutde during the esrig part of tho oxaninstien and ovenariesd exdoting Inforastion eoneorning the geologr, produetion, and oubors.

The Starte alne was prevlouely oxantined for Nuoreper by Cex and Oreager $J$, and Thuriton $J / 3$ and for trace elesants by cheatorean and

I Cox, D. C., and Orsnger, A, Z., VIuorapar Investigatione

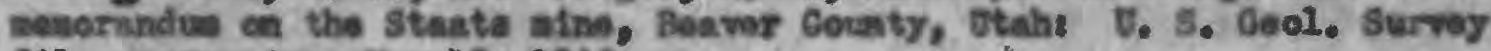
P110 mozernindu, Ilay 19, 1943.

J Thurnten, $1 . R_{0}, 00$, alt. 
Hain $\perp$.

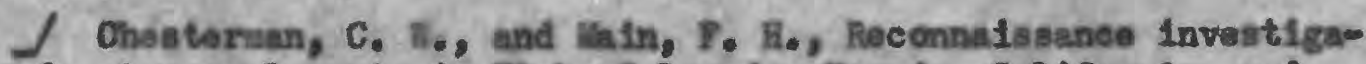
ticas for trace elebonts in Vtah, Colorado, llevade, Callfornis, and Oregon, prelinfinery roports $\quad$ U. S. Ceol. Survey Trece Elesents Investigetiona Rspt. 26, pp. 24-25, 41, mpublisbed, 1947.

The purpose of the prewent exainination wall to study workfings not provlousis exanined by Chesternen and lain, to take standard 2- by 5-Inoh ohamel sanplos of representative roek types, and to reappralse the goology in view of the rolatively hich poroentages of uraniule detsrained in the 4 semplos taken by Chesternan and Hain, (Trblo 1 ).

Table 1. Insigres of nowples taken by Chesternan and thein

Sasplo number

$0-21-90$ altered shyolita

C-11-91 fluorapar win near foult

0-11-92 f luorspar and 1rritating gas

C-11-93 masive Ruorspor
Descript1oe

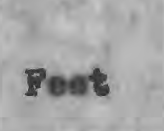

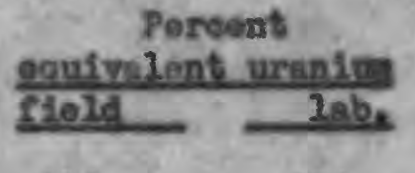

5.010

2

.048

จ. .051

3.238
Percent urantia ghenten

.06

Resurves given by Chestarnan and la in based on exposures seen by thea in 1945, and analyoes tabulated above, were 8,000 tons containing .07 peroont equivalent uranilum.

\section{Hatory and production}

Fluorite was discovered in the ares ebout 1935, and sabe fluoraper has bash aisod gourly since then. Tothl produotion to January 2946 in estinated by Thurstion $\mathcal{J}$ to be 3500 tons of fluoraper of 


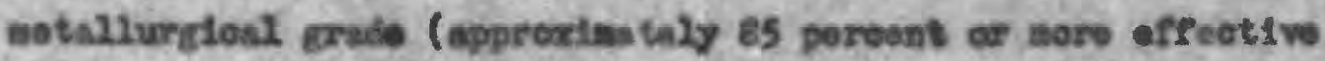
$\mathrm{Ca} / 2)$.

The proporty, Inoleding about 10 elalen now onllad the lomeroh group, belongs to Itr. Frod stanta of Selt Lake CAty. Tormerly, the

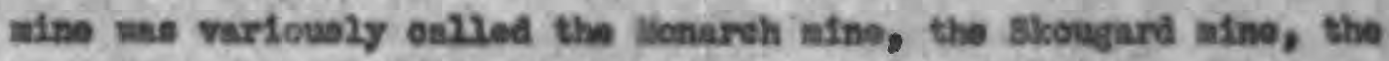
Roberts and skougard ains, or the Roberto and Stasts mino, reflecting the suecesatve omere' names.

\section{ascicor}

The goology 18, in genaral, steples in datall, cooplex.

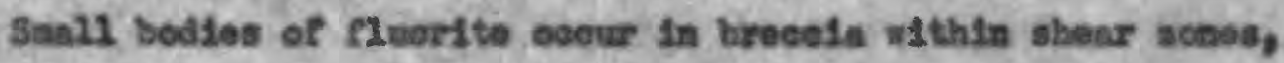
Which apperontiy fore the conteet betwoen rigyolite porphyry, and Canbrian (v) 1inatom. The bedy of rhyolite perpingry is roughly elliptleal in shape, and on the arder of 3,000 roet in length, and 500 feet in w16th. It is entirely murrounded by lissatone. Beceves

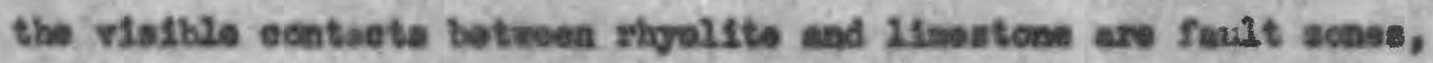
2t is not knowa whother the riyolite porphysy is Intrualv or extruaive In orlgta. No efentefient ecateot netanorphisa sas obeerved.

The tarn latsto (1) has beon used in provlous sesorands becevias Ornager reports that several thin sectsons ahomsd the apporoxiente

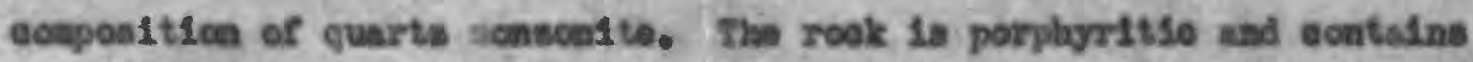
pheneeryste of foldeper, probehly orthoelese, and quarts in a finegrafned groundeses, Thursten cells the roek rihyolite porphyry. No plegloelaes wa noted sogaseopleally. Provistonsily the tera rhyolite porphysy mould te uaed pending additiensl atudy of thin sections, Uneltared rlogelite porplyyry la daxk ervi. 
As seen in the workings, the breocis sone formed by faulting et the contact of rhyolite porphyry and If mestone is thoroughly alteredy Alteration obliterated noet of the original textural features of the porphyry and loft a mass of soft eley containing a fow unnltored, relict ouarts phenoerysts. The altered rock is white or 11/ht buff.

Faults within the contact sone ere nuserous. They whow many varistions in strike and dip within ohort horisontel distances. Proguesaby the breccia zones eerved as channels for hydrotherwal solutions that introdueed fluorite and other minerals. Faulting probably occurred both before and after soce of the fluorite was Introduced.

Deep purple, nearly bleek Pluorite occure we volns, velnlets, Irregular eases, and brecclated fragmenta in small pods or Irregular sones vithin the fault breccia. The fluorite-bearing pods range from 6 Inches to 6 feet In wath and from 5 feet to 25 reet in 1ength, and are reported to extond mors than 25 feet in depth.

Sall ereas of fluorite in the loner workings are couted wth uranium-bearing minerale that fluoresce under ultre-violet light. Aceording to Crenger, samples of this anterial sent to Dr. W. F. Foshag, U. S. National Mhaseum, by 1 r. Staeta wero roported to cortain autunite and urapophane. No wraninfte has been 1dentiried. As the autunito and uranophane coat some of the fluorite, they were evidently farmed aftex the fluorite, probably by alterution of some other unidentifled wineral contained in the fluorlte or associated with It.

\section{mORKxings}

The rorkings consiat of an open eut, a shaft, four adite, and 
several sandl pite (FIs. 1), The open eut and shaft are sppresssataly 300 foet nerth of the pertal of the adit, hore ealled the Lonez adit. Th1s edit in abut 230 foet loag, panotrates the foult brase is at the eontaot between IInestone and Flyollta, and exposes a mall nuorwper pod. Abert 600 fout northeant of the portal of the Loser ad1t are a Group of sall ptts, ealled in this report the Sadals rorkinga, whlah expose soes nuorite asases in the fault zone.

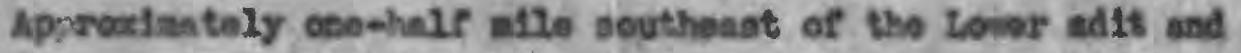
outalde the aros of FIguv I, another smell fluorite pof has bean renched by an sast spproxilestaly 200 feet long, and e winse, roported to be 65 seot deop. The sdit and wase will be oullod the ratot worktags. About 500 foot noutheast froe the point workinga to whert

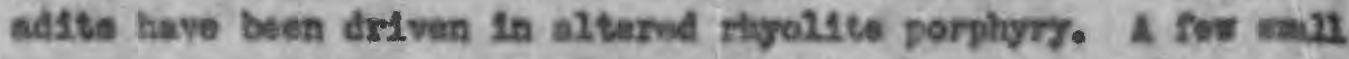
pleces of fluorite vere obsarved in the nalls of the sdits,

\section{Rastouorivirt}

\section{Baruments at the outeren}

Rediosotivity wall mensured at the outerop on all types of rook, and a Goleor eounter traverse wa sade cerves the body of rhyolste porphyry. The fluoritoobearing senee shored tho noet radloeotivity the Ifmestone is not radiowetives and the body of rtgolite perphyry 1s fros 3 to 4 timas sa redionotive as the background observed in the 11matone (aoe $\mathrm{fft}$ I - Celpor travoras). Counts at the outerop, in-

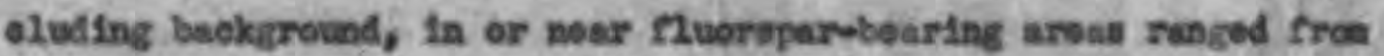
epproximately 50 to 150 per alnute, in rhyolsto porphyry tres 24 to $37 \mathrm{per}$ sinute, and in 11 asotene rrom 8 to $15 \mathrm{per}$ niauts, 


$$
-6 .
$$

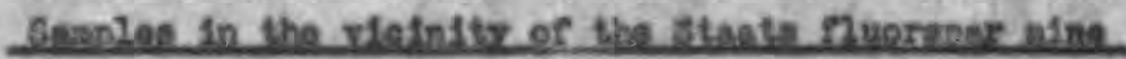

Seaplas were takon of all roek tJpea obsearved. The 23 sanples wre redueed in the Donver sample preparetion letorstory and eoratod In the offlee ath flold Instrimont number G,5, 2, and Impulae roglatar.

Cuality control sethods vire uned in mescurosint of the redio-

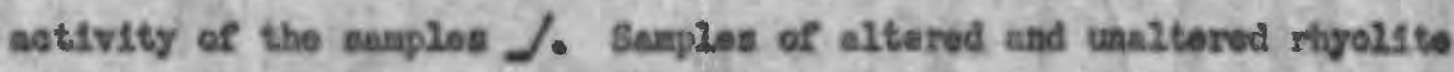

$\perp$ Sehleoht, 8. Q., Centrol ohart sathod epplied to errora in radicective counting: 0. S. Geol. Survey Treoo Ilenenta Investigaticno Ropt. 28 (ievc-695), unpubiliehod, 1946,

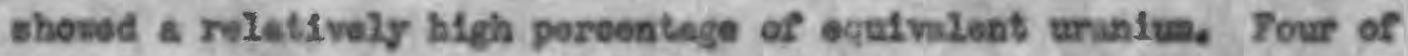
Whose senples, belloped to be repsesontstivo of the altared and unaltored rhyollts, verv etosen for ehenafes snelysea.

The reaulta of the radsoativity doteratastions and of ehealoal anklyees of tour sanples (Table 2, Aypendis) Indieates

1) Thet the sateple contalning the noat radicsotivity (0.4 percent equivelent urantua) 10 Mo, 1328, s aupled pleked by ultre-violet 11ght for 1te high eutunite conlent.

2) That somplon of Slvorste and fluoropar ore, excluding Ho. 1328, contatn fron 0.02 (No. 1326) to 0.07 pereant equivalent urantua (10. 1322).

3) That eamise of altered rhyolite perplayry adjacent to nuorapar ore ocntalin from 0.03 (No. 1327) to 0.057 poroent equivient

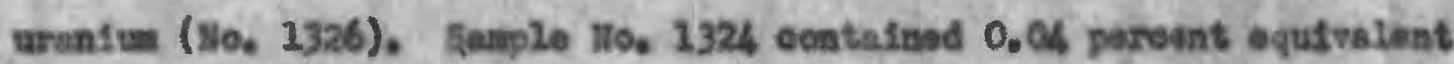
urenftes, 0.032 percent $\pi_{0}$, and 0.002 peroent $\mathrm{ThO}_{2}$. 
4) That senples of altered rlyolite gapplyry not adfeoont to Ruorepar ore euntain from leas then 0.065 (No.s. 1315, 1320, 2322) to 0.007 poroent oquivilent urenilua (Hos. 118, 2927). Banple No. 1318 contained 0,007 pereent opuivelast urinitu, 0,003 peroent $V$, 0,004 parseat $\mathrm{ThO}_{2}$.

5) Thit sasples of andtered slyolite porplayay, I0s. 2323, and

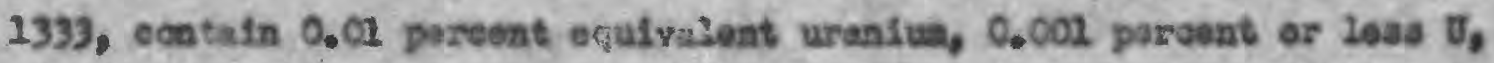
and 0.002 percont $\mathrm{ThO}_{2}$ ! and 0.006 percent equlveleat uraniua, 0.001 parcent $v_{1}$ and 0.003 parcent $\mathrm{ThO}_{2}$, respat 1 raly.

6) That the 2 tasatone 10 not rudioative

7) That 0.06 pereent equivalont uraalua is loft in the tislinge after the fuorspax is extrieted frear the aill.

\section{Other imeous bodtes}

There are in the generil ares other bollies of 1 gnoous rook mimilar to the one at the Stants nins. Their sise, and aumber are not kaom, nor is it known whother or not they are radioeotive.

One sueh body of rhysilta (3) is porhape a w12e ouat-northeast Fren the loser adit of the Etante alno. The eres is known as the

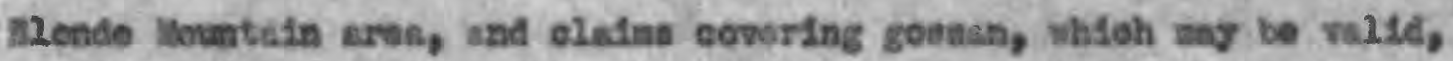

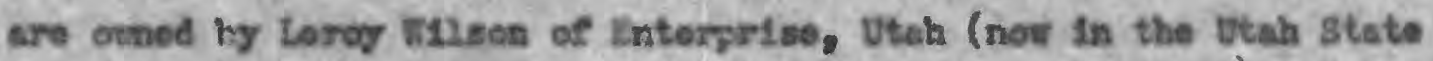
Penitentiary), end Edwend II. Parry of Coder C1ty, vteh,

Shaplos sere triken of goosen exponed in a shallor shaft at the centect of the 1gneous rock and ourrounding 1 inostens. Semple Ito. 2312 twken nerosi 5 feet of gonen eentaine 0.006 por-

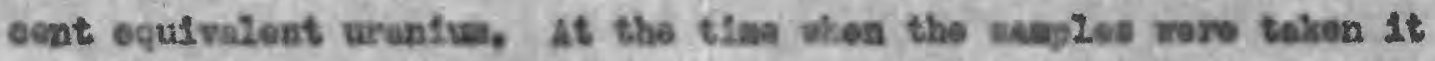


wal not known thet the unaltered rhyelite porplyyry at the staste

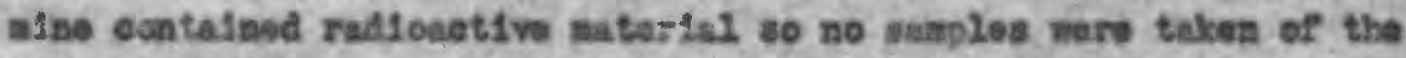
Ignoous rook of Blonde Hountein.

\section{Ressives}

The data are Ingucfiolont for engthing but rough approxisations of resorves.

It wa first believed that the asoples of unaltared rhyolite perphory econtasined nore than 0.01 pereent eculvilont uranita and, therefore, that the large tonnage of uneltered rhyolite porphyry aovild

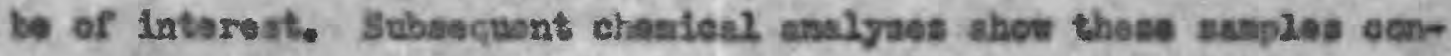
tale on2y 0,002 pereent, or 2ess, $U$ and 0,0025 pereent $\mathrm{ThO}_{2}$. Therefore, the aadn sody of rhyolit te is prosusal:2y not of intariat.

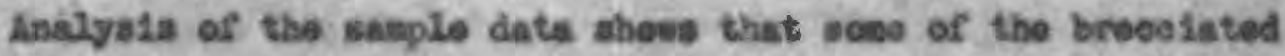
altered rhyolute sdjeeent to the fluarlte masses and voinlets ochtalns epproxinstely the ause ceout of ecuivelent urentie se dess the

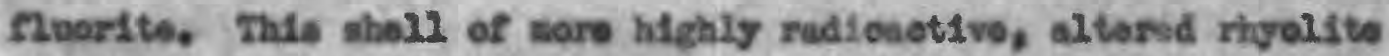
10 frae 2 to wore than 5 roet wide. In tae of the three places sasplod the shell was on the rhyollte perphyry side of the fluorlts mas.

Beserves of nuorspar ore and the shell of sltered rhyolite porphyry adfaeent to the nuorite in the staste rorkinga are eatlasted to te 10,000 teno of rook coentalintag 0.03 peresnt equivalent ursaium, 0,032 percent 8 , and 0,002 peroent $\mathrm{rtO}_{2}$. The eotisiste tis based sa the anslyses of sesples, on the anvint of fluorsper produned, the

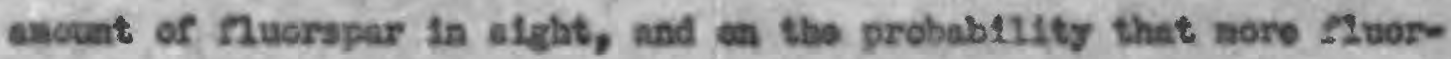
eper wlll be diseovered. 
Acoerding to the map $\left(\mathrm{fIg}_{\mathrm{g}}\right.$ 1) there are over 2,000,000 tene of altered, bresclated roak for ench 200 foet of depth axound the body of waltered rhyalte porphyry. It is within this sone thet the knom fluorlts ore bodles ocour.

The sasple dets sugsesit that soet of this altered rosk not Olosely sascelated with fluorupar ore bodigs conteins ne wore mileaotivity than doos the acin bedy of rhyoltte porptyry. The averege of ofx t1old anslyses is 0.006 percent oquivalent uranitu. One of the 'aix samples conlalned 0,003 porcent $v_{1}$, and 0,004 porsant ThO2.

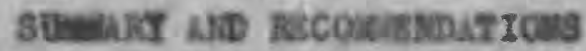

Radienetive Ruorite, altered zhyolite porplyry, and unsltered rhyoltte porphyry oevir at the stakts atne.

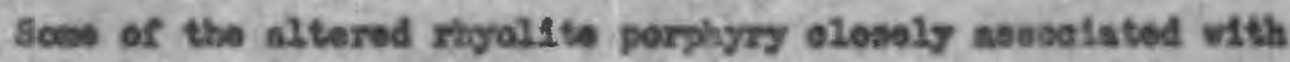

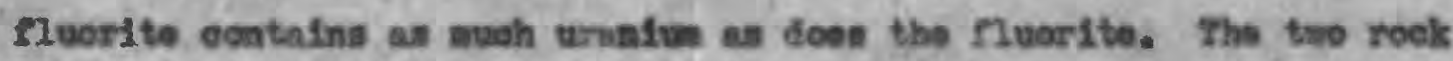
typea ean be lunped together to glve a reeorvo of approsinstely 10,000 tons oontefning 0.03 parosnt eculvalent urinlus, 0.032 percoat D, 0.0QA porosnt $\mathrm{ThO}_{2}$.

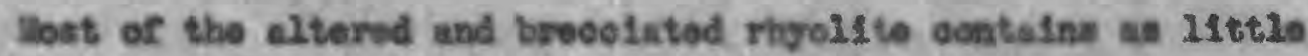
urantion and thorlua al does tho uneltarod rbyolste. The eoshtnod roserves of altered and maltered shyollt to an more then 12,000,000 tons for esah 100 feot of depth but the gralle averages only 0.006 pert cent oquivalent ursalum and about 0,002 pervent 8 and 0.003 porcent $\mathrm{ThO}_{2}$.

Chendend ennilysis of four eseples has denenstrated that the suln

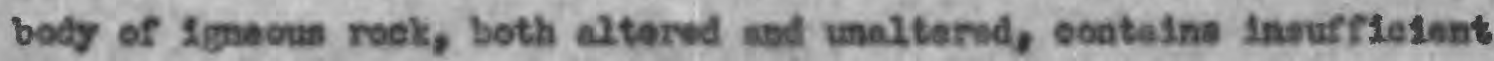




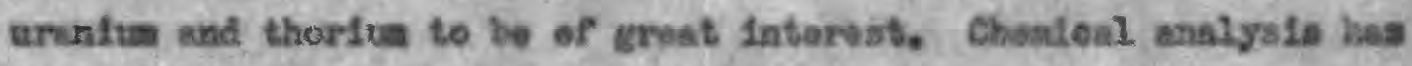

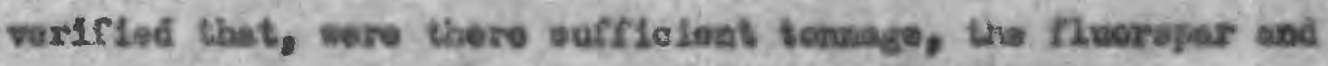
sesoolated sltered rigolite al obt be of intsrest.

The deatrobility of doing nore nork in the exes dopande of several feotora!

a) The dentro swd need for pose dotafied bovilodep of the

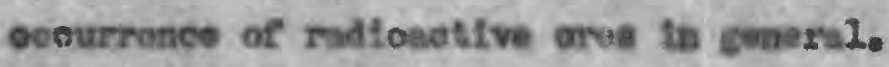

b) The posafbslity that nore astartal coataining 0.03 poreent U ney be discovered.

c) The posstbility that aore nork would - tring to light othor bodles of redsoeotige rook in the general aren.

d) The fact that ald axaninations of the stuats nine to date kave been of the reconnalssunce type, whe the fath, therefore, are

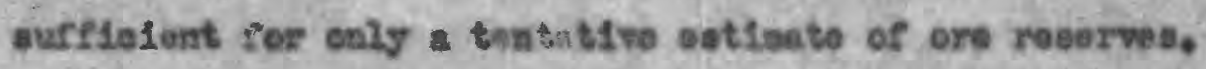

The roldtively acall tonkec of ore that ean be Inforred frem prosent rorkinge and surfece expocuses make deukteral the poselbility of any subetantis prolustion froe the stakts nine sad violnity. A aere definttive spprated would reculre ofther unsowertag the zcene of alteration alone the sontast between the rhyollte and 11 sestone if trenching, or drilling. Drilling would tout the oxtant of the radoactive storation sone at depth, I fow $4 \times 111$ holes to nderete depthe vould be the moet eoneluselve nothod of coternining whother the redicoetive sone of altored roek is exthasive and distributed uni-

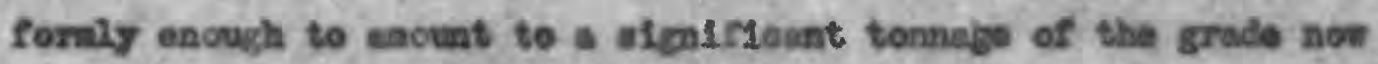
Inferred. If the diatribetion of atarlal of ouftable grade is 


$$
-21 .
$$

thestlefectory otior dotilled work would not be murvated. brilling

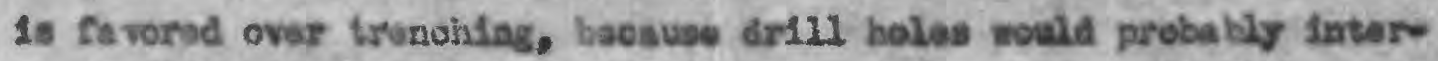
seet the sons of altorvd rook be2ow the depth at which it in affeated by westhoring. Trunehing belew the Gapth of posulbio veathering any not bo founfole. 
母

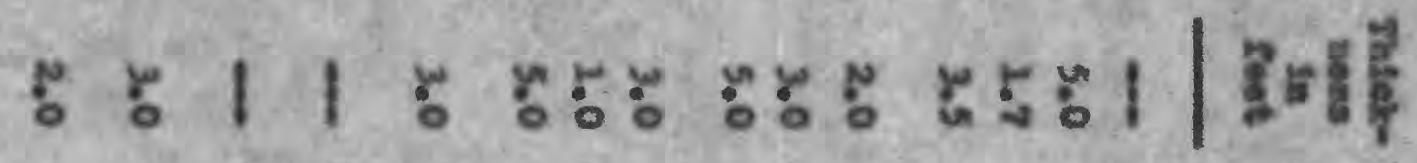

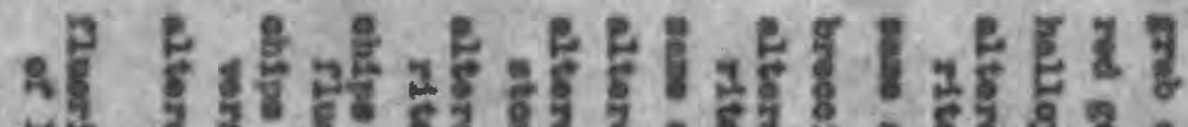
药 1.

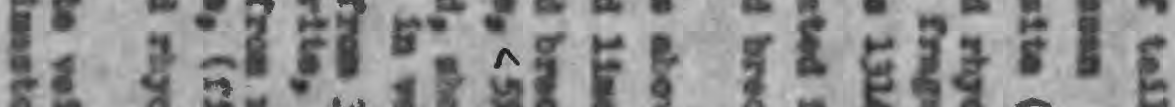
If

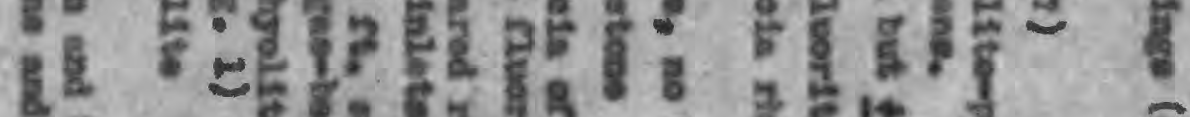

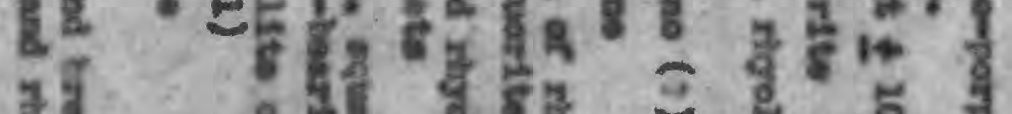

数 का हैं i

I. है है।

के $\frac{1}{8}$

$1 \%$

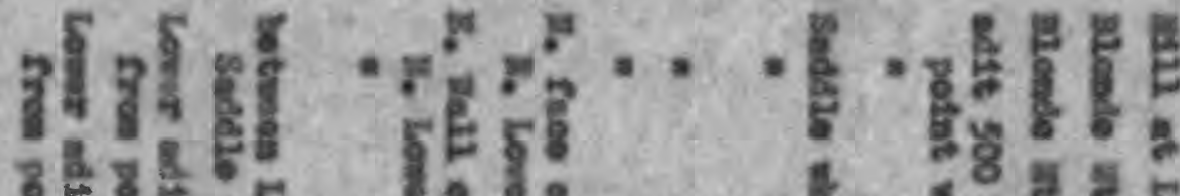

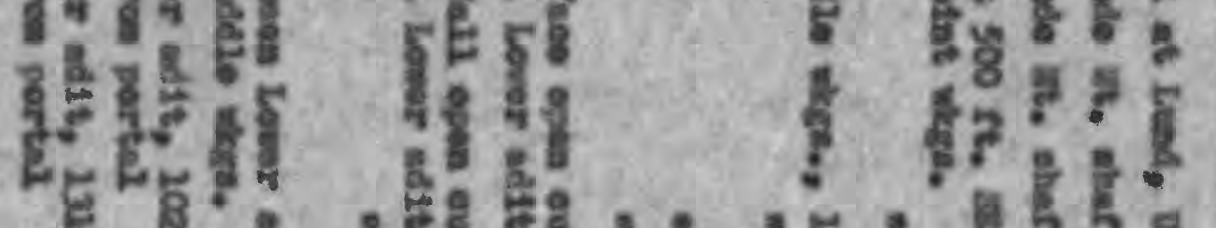

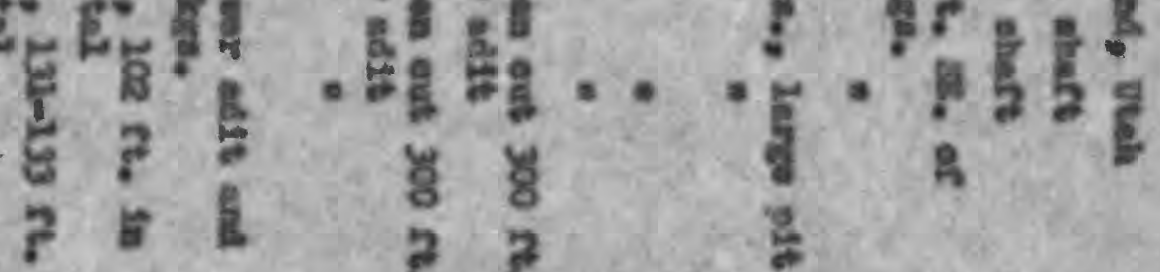
? ? :

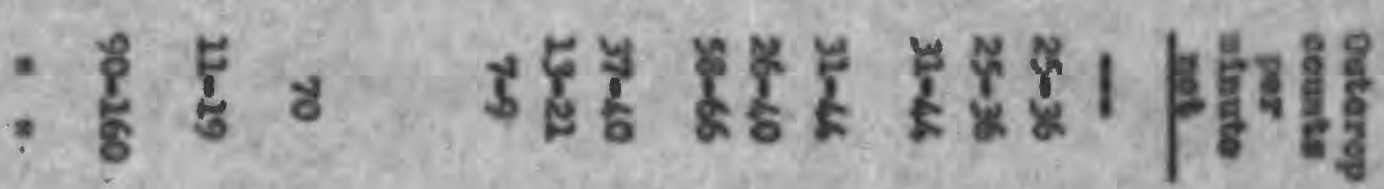
है $\frac{8}{8}$ ㄴ. है

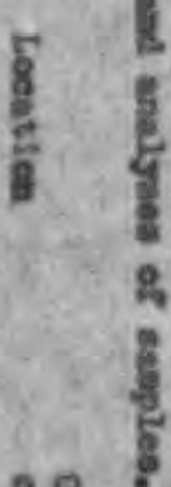

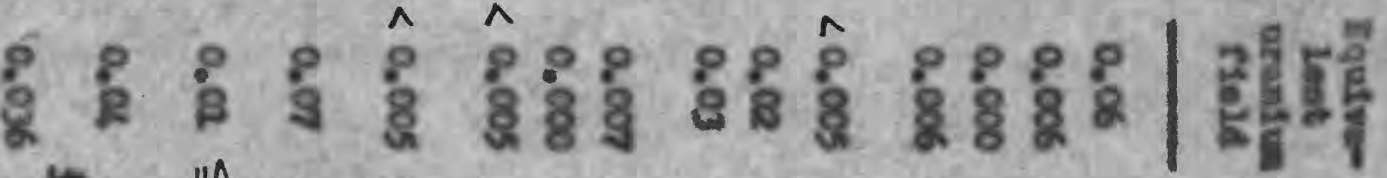
$\because 8$

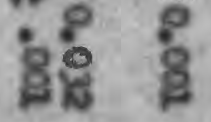
: 웅 


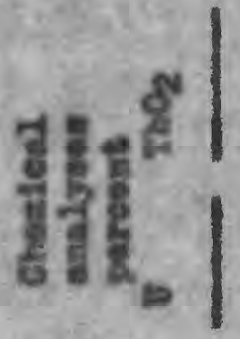

8

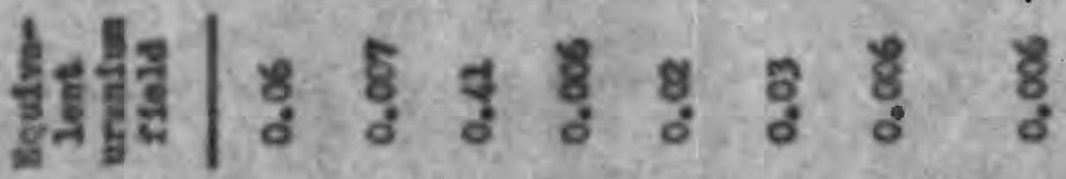

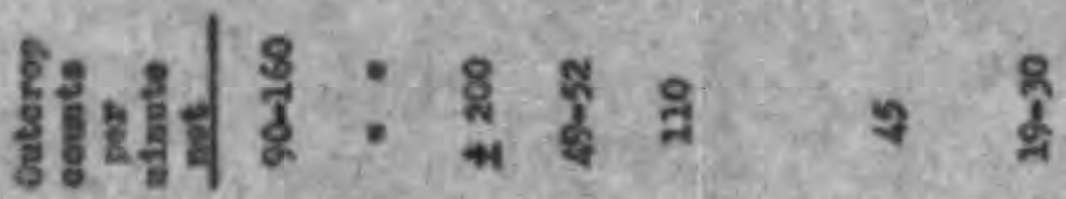

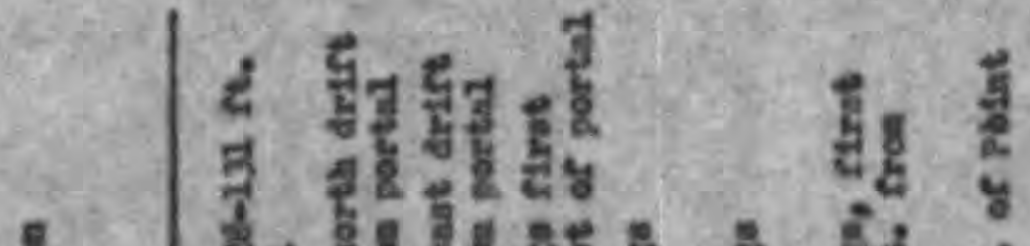

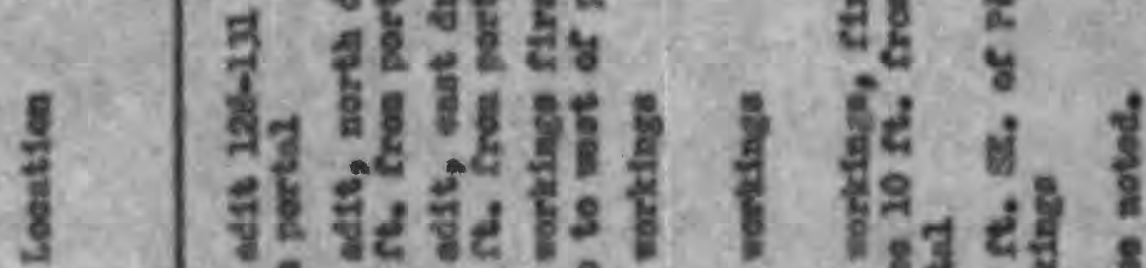

달

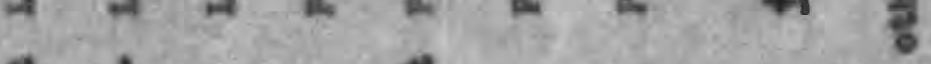

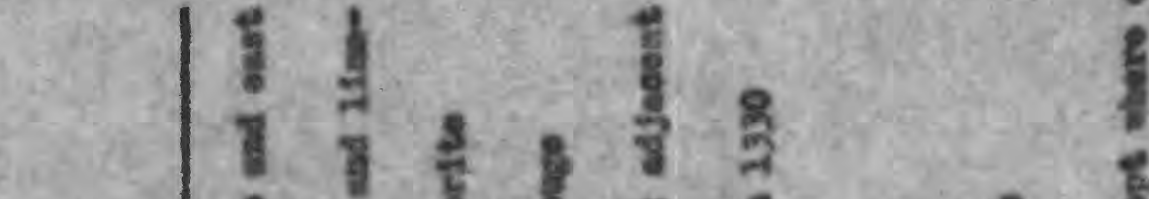

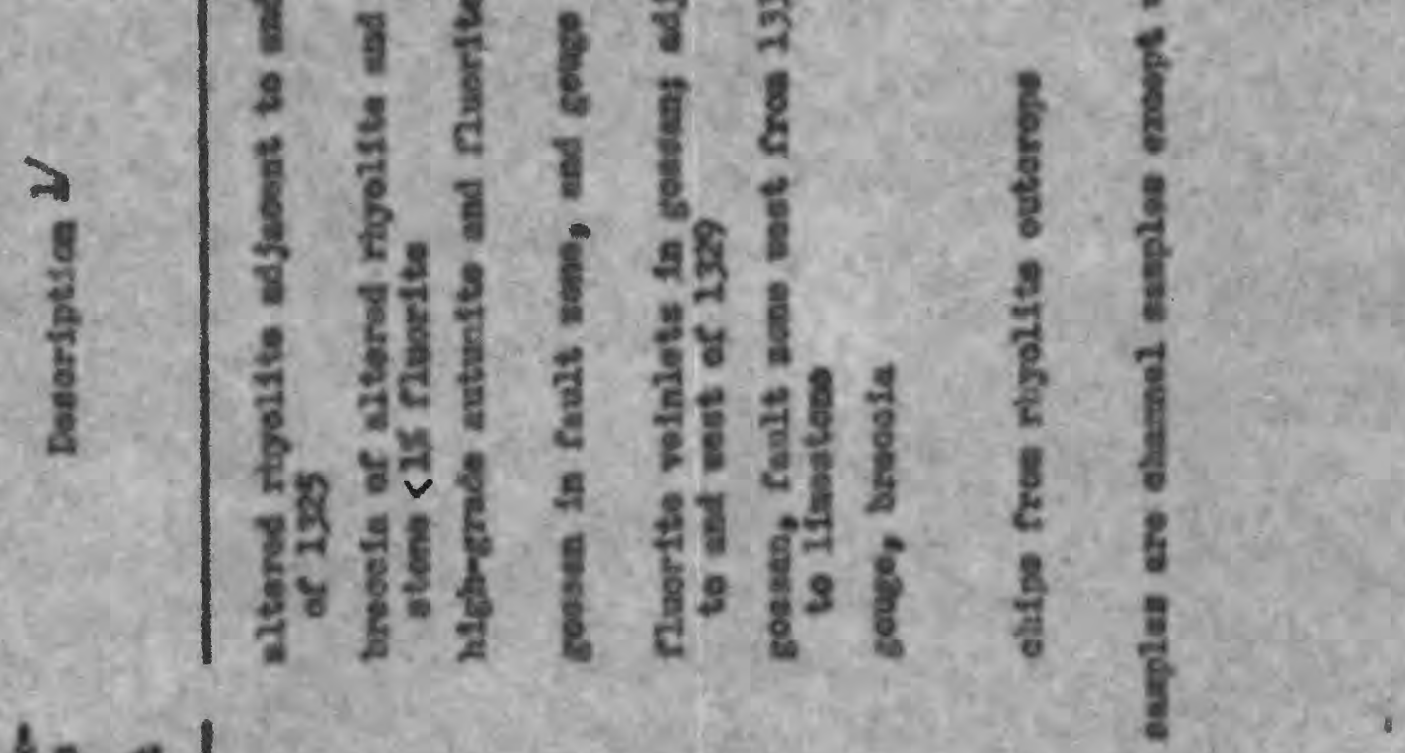

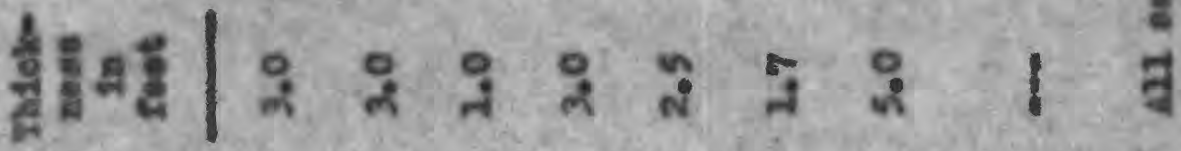

辣 $125 \%$ 


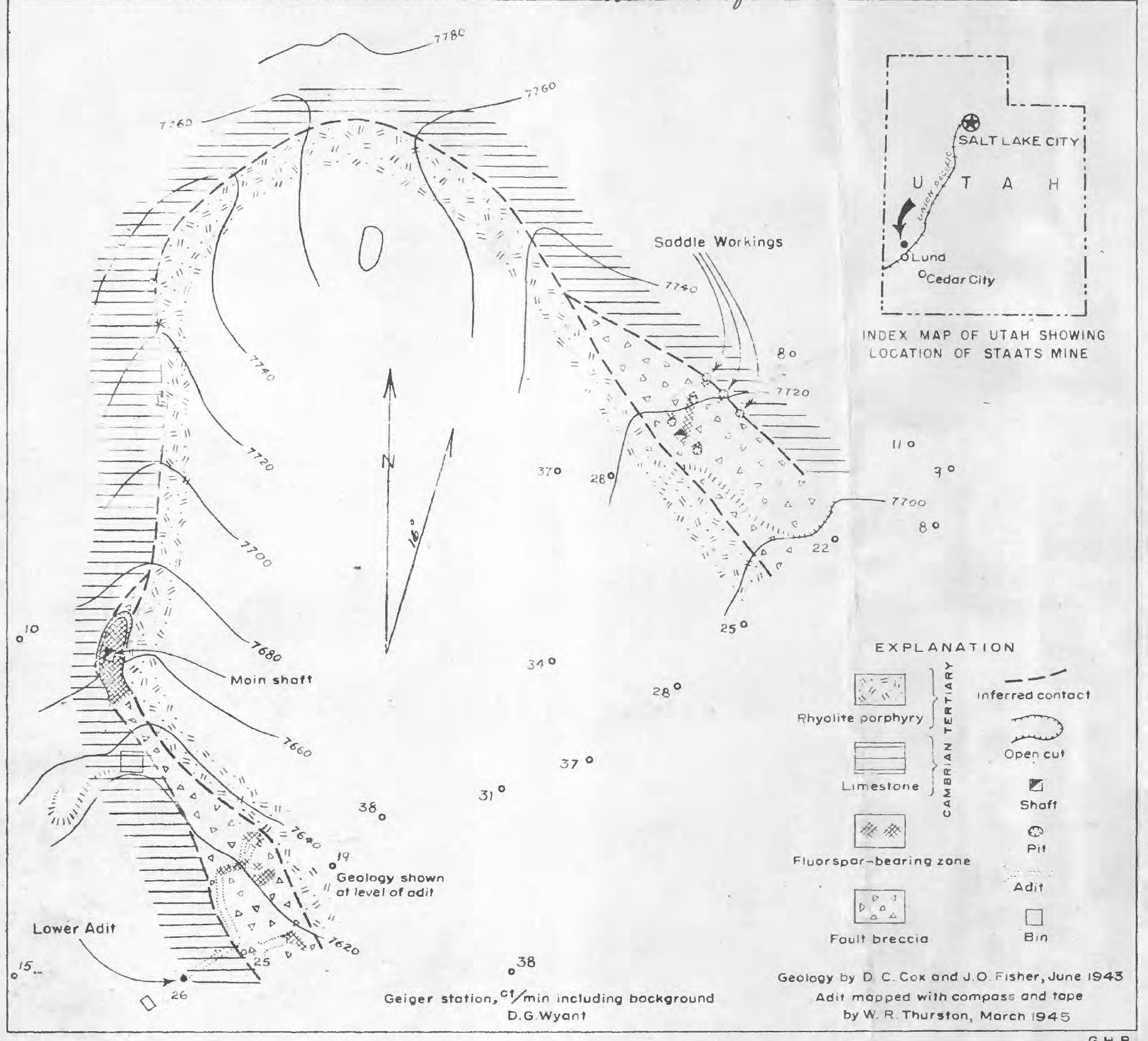

SKETCH MAP OF GEOLOGY IN VICINITY OF MAIN SHAFT

STAATS MINE, BEAVER COUNTY, UTAH

100
$\substack{\text { Contour interval } 20 \text { feet } \\ \text { Datum assumed }}$


NO. RA-52

\section{RECIASSIFICETION AUTHORIZATION}

In accordance with the authority delegated to me by memorandum from the General Manager, dated December 6, 1948, subject, "Security Procedures and Policies relating to the Domestic Raw Materials Program"l and based on criteria for determining classification, as outlined in Appendix A attached thereto, the document(s) listed below are reclassified as indicated.

\begin{tabular}{|c|c|c|c|}
\hline & & $\begin{array}{c}\text { Present } \\
\text { Classification }\end{array}$ & $\begin{array}{c}\text { Revised } \\
\text { Classification }\end{array}$ \\
\hline (I) & $\begin{array}{l}\text { USGS - TEI Report No. } 38 \\
\text { "Trace Elements Reconnaissance along } \\
\text { Highways in the Tanana and Upper } \\
\text { Copper River Valleys, Alaska" by } \\
\text { H. Wedow, Jr., and J. J. Natzko, } \\
\text { dated March } 1947\end{array}$ & $\begin{array}{l}\text { OFFICIAL USE ONLY } \\
\text { Ig }\end{array}$ & UNCLASSIFIED \\
\hline (2) & $\begin{array}{l}\text { USGS - TEI Report No. } 50 \text {-- - } \\
\text { "Staats Fluorspar Iine, Beaver } \\
\text { County, Utah (Memorandum Report)" } \\
\text { by Donald G. Wyant, (undated). }\end{array}$ & SECRET & UNCIASSIFIED \\
\hline (3) & $\begin{array}{l}\text { USGS TEI Report No. } 52 .- \\
\text { "Radioactivity of Sediments in } \\
\text { Parts of Oklahoma and Kansas" } \\
\text { by Garland B. Gott, September } \\
\text { 1948. }\end{array}$ & RESTRICTED & UNCIASSIFIED \\
\hline
\end{tabular}

Fat

Date

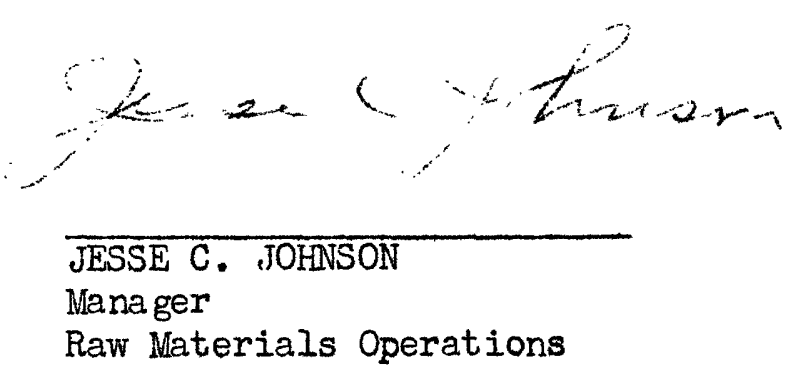


WASHINGTON 25, D.C.

Mr. William P. Huleatt,

U. S. Geological Survey,

Box 2746, Lakemood Branch,

Denver 15, Colorado.

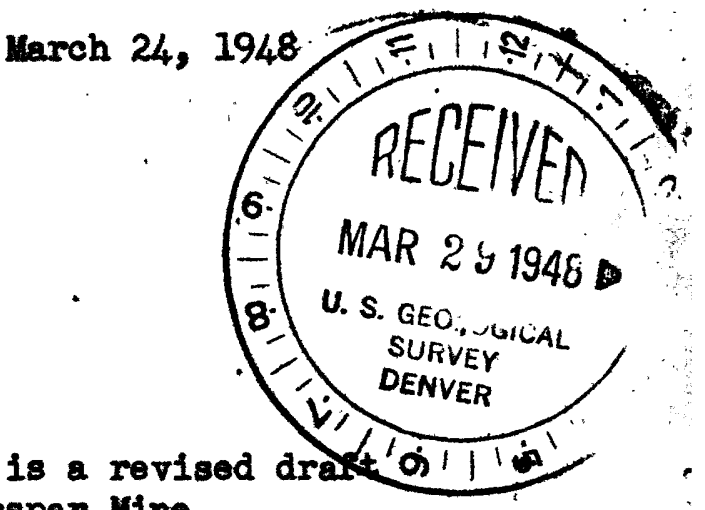

Dear Bill:

Enclosed for Don Wyant's and your approval is a revised of Wyant's memorandum report on the Staats Fluorspar Mine.

The chlef changes are editorial and have been made to make this report correspond more closely to the format and editorial arrangement of the more formal reports. This has been done for uniformity in presentation of all reports in order that we nay adhere to one editorial standard rather than several. This simplifies the editing job as only one type of procedure has to be followed. Fe have eliminated certain explanations with regard to the standard sample, and with reference to the quality control method as being our own problem and not pertinent information for transmission to the Atomic Energy Commission.

It also seemed that the statements about "Other Igneous bodies" fitted into the general composition of the report better by including this section under "Radioactivity measurements" instead of placing it after Economic significance". The chief change, however, is in "Recommendations". Tom Hendricks wonders whether we would ever get an answer by surface work alone chiefly because of the difficulty of getting samples that would not have been affected by weather For this reason drilling has been suggested as the best means of determining whether the bodies of radioactive rock are sufficiently continnous to give the hope of any sizeable tonnage. We have not changed the appendix table and for that reason it is not included with this draft of the report. It $w i l l$ be inoluded in the final report in the form in which you submitted it.

Te are planning to prepare 8 copies of the final draft of the report for the use of the Atomic Energy Commission and ourselves. When you have looked this draft over, will you please return it with your approval or with your suggestions for any other chenges. Ne should also like to have enough copies of the map to go with this number of reports. I believe it is not necessary to include the control charts. If however, you wish to have them included, they should be dram on tracing cloth and prints should be me.

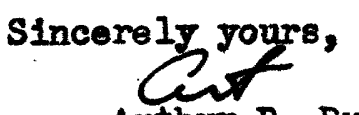

Arthur P. Butler, Jr. Prece Ilemente Office 
Box 2746 Lakewood Branch

Denver 15, Caloredo

Ias 20,1948

It. Thomas A. Hendrick

v. S. Ceologleal Survey

FWA Butldins

Nashington 25, D.C.

Attention: 4. P. Butler, Jr.

Dear Tons

Bncloeed 10 the Staats ruport.

I agree with your suggestion to aubotitute core drilling for trenching.

On page 12, I an Inolined to agree with Wyant with regards to his marginal note concerning 11 nes 11,12 , and 13.

The Shinarump Hose roport should reach you by Monday at the latest and Brl11' repert (Reconnlasance of Pegmatite Dikes and Associated Rocks in the Front Range of Colorado) will follow as soon thereafter as wo can got 1t out.

\section{Sincerely,}

Tim. P. Huleatt

Goologist

\section{Tne looure}

$\mathrm{WPH} / \mathrm{fd}$

(Secret report - 14 pages, No. 1 of 2 copies with 8 sketch maps enclosed, report is original copy)

Sent Registered hail- Air mail. 


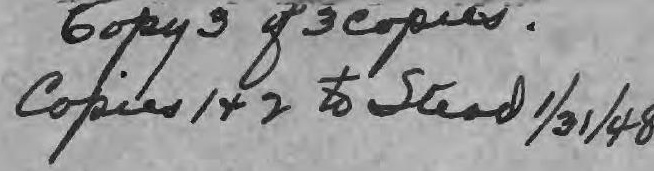

Denver, Colorado

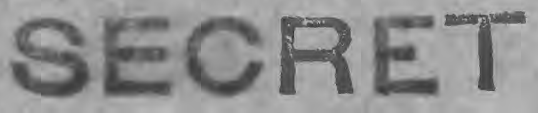

STAATS IINE BEAVER COUNTY, UTAH

Bxcamined and sampled in 1945 by Chesterman and Uain

Examined and sampled in November, 1947 by D. G. Wyant

\section{Chesterman \& Maln's Samples}

\begin{tabular}{|c|c|c|c|c|}
\hline No. & Description & Pleld & $\underline{L a b}$ & $\begin{array}{r}70 \\
200 \\
\end{array}$ \\
\hline $\begin{array}{l}-90 \\
-91 \\
-92\end{array}$ & $\begin{array}{l}\text { Altered rhyollte } \\
\text { Fluorspar in vein near foult } \\
\text { Pluoropar (gasey) } \\
\text { Yassive fluorsper }\end{array}$ & $\begin{array}{l}0.010 \\
0.046 \\
0.051 \\
0.238\end{array}$ & $\begin{array}{r}0.093 \\
.625\end{array}$ & 0.06 \\
\hline
\end{tabular}

Reserve by Chesterman and Yains 8000 Tons or .07 0 .

Evant's Samples (23)

\begin{tabular}{|c|c|c|c|c|}
\hline Ho. & Description & tod Pleld & 80 & $\mathrm{mO}_{2}$ \\
\hline 1311 & Mill tails & 0.100 & & \\
\hline 1312 & Reddish gosean & 0.009 & & \\
\hline 1313 & Halloysite? & 0.000 Low & & \\
\hline 1314 & Altered latite & 0.009 & & \\
\hline 1315 & Altered latite \& fluorite & 0.007 & & \\
\hline 1316 & Brocclated Pluorite & 0.032 & & \\
\hline 1317 & Altered brecelated Iluorlto & 0.044 & & \\
\hline 1318 & Altered latite & 0.011 & 0.003 & 0.004 \\
\hline 1319 & Altered IImestione & 0.000 Low & & \\
\hline 1320 & Altered breccia & 0.004 & & \\
\hline 1322 & Altered latite & 0.007 & & \\
\hline 2322 & Dark, gassy Iluorite & c. $217+$ & & \\
\hline 1323 & Lat1t outcrop & 0.016 & 0.001 & 0.002 \\
\hline 2324 & Altered latito & 0.065 & 0.032 & 0.001 \\
\hline 1325 & Pluorite vein & 0.059 & & \\
\hline 1326 & iltered latito & 0.092 & & \\
\hline 1327 & Altered latite brecela & 0.012 & & \\
\hline 1328 & Fivorite \& autunite & 0.660 high & & \\
\hline 1329 & Gossan & 0.009 & & \\
\hline 2330 & Fluorite veinlote in gossan & 0.033 & & \\
\hline 1332 & Gossan & 0.050 & & \\
\hline 1332 & Gouge fron drift & 0.010 & 0.001 & 0.003 \\
\hline 1333 & Latite & 0.010 & & \\
\hline
\end{tabular}

Four samples $(1318,1323,1324$ 1333) selocted for chemical analyals on basis of tonnage represented. 
Samples 1323 \& 1333 represent app. 10,000,000 I of

$\begin{array}{ll}\frac{80}{0.001} & \frac{8 \mathrm{ThO}_{2}}{0.0025} \\ 0.0175 & 0.0025\end{array}$

Chemical analyses appreolably lower than fleld counts.

\section{Month of January}

Chemical analyees recelved January 29,1948

Conclusions Results of work completed to date are ditsappointing. Additional work advisable 


\section{UNITED STATES \\ DEPARTMENT OF THE INTERIOR \\ GEOLOGICAL SURVEY}

DENVER OFFICE

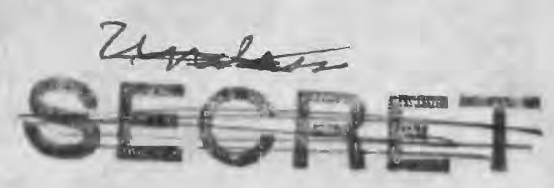

TRACE ELEIENTS SECTION

Staats Fluorite Froject, Utah

Wonthly Frogress Report for December, 1947

Introduction: The Staats fluorite mine, in the southern part of the Wah wah Range, Beaver County, Utah (see attached index map) was examined briefly in November. The report, including detailed recomendations for future work is ready for final typing.

Progress during December:

(a) -Geologic results....

On the basis of percent eU determinedin samples at Denver, highest grade ore $(0.1$ to $0.66 \% \mathrm{eU})$ is associated with fluorite. The amount of such material "in sight" is small. Samples of fresh latite(?) porphyry contain $0 Q_{1 \%}$ or more eU, and the amount of such material "in sight" is large.

(b) Changes in objectives:

Emphasis should be nlaced on determining the amount of radioactivity in the latite(?). See recommendations below.

(c) Specific recommendations for any reorientation....

A long range project should be established involving:

I) detailed mapping of mineworkings and the bodye of radioactive igneous rock;

2) areal mapping of parts of several $7 \frac{7}{2}$ minute quadrangles to establish the general geology and locate for detailed work several other igneous bodies which may be radioactive;

3) sampling of the latite(?) porchyry at the staats mine, to be followed by diamond drilling if sampling warrants it;

4) investigating in the laboratory the mineralogy and petrology of the rocks.

(d) An estimate of the economic results to date....

There are roughly 10,000,000 tons of latite(?) porphyry

for every 100 feet of depth at the Staats mine. On the basis of field sample count the latite (?) contains $0.01 \%$ or more eU.

(e) Probable date of completion....

No long range project has been set up (see recomnendations above). The report of the examination made in November is ready for final typing.

(f) Degree of completion and probable date of transmittal.... Not pertinant, see (e) above. 
Conclusion: If chemical analysis of the four samples sent to Washington confirms the amount of eU determined by field samole count ( $0.01 \%$ or more), the long range program outlined in (c) above, and more fully detailed in the forth-coming report of the November examination, should be started .

The Wah Wah hange is relatively high but should be sufficiently snowfree by April to permit field work.

lian months completed in December: Proffessional--0.3 of one manmonth, office work.

Personnel: Donald G. Wyant

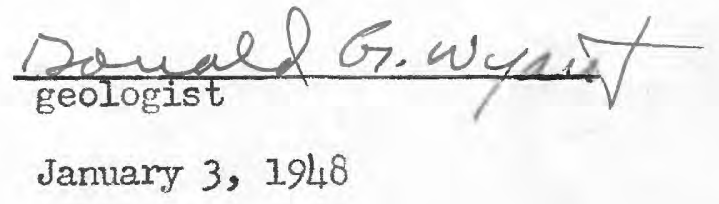

DCW /aw

Figure 1 attached

$1 \mathrm{cc}$ Washington (Hendricks)

1 cc Denver

I cc author (originator) 
The Staats mine is near the southern end of the Wah Wah Range in the southwestern part of Beaver County, about 32 miles by road from Lund. The ore is a deep purple luorspar which occurs as lenses and veins in altered rhyolite and silicified limestone. The mineralized zone, which includes the fluorspar veins and the adjoining altered rhyolite, is from 5 to 7 feet wide and is well exposed in lower and upper mine workings which are about 200 feet apart horizontally. The fluorspar in several small lenses contains an irritating gas.

C-11-90 altered rhy. - .0010

c-11-91 fluor-vein ca fault - .0048

C-11-93 massive fluor. $\quad-.0238$

C-11-92 fluor \& gas $\quad-.0051$

Both mine workings $8000-.007$

$\begin{array}{lllllll}\mathrm{C}-11 \text { Fluor } & \# \text { sta. } & \#{ }_{3}^{S} & \text { Ft. } & \text { F } & \text { L } & \text { C } \\ & & & .0238 & .0625 & .045\end{array}$

$\begin{array}{lllllll}\text { Rhy } & 11 & 1 & 5 & .0010 & .0093 & .006\end{array}$

Limestone $\quad 3$

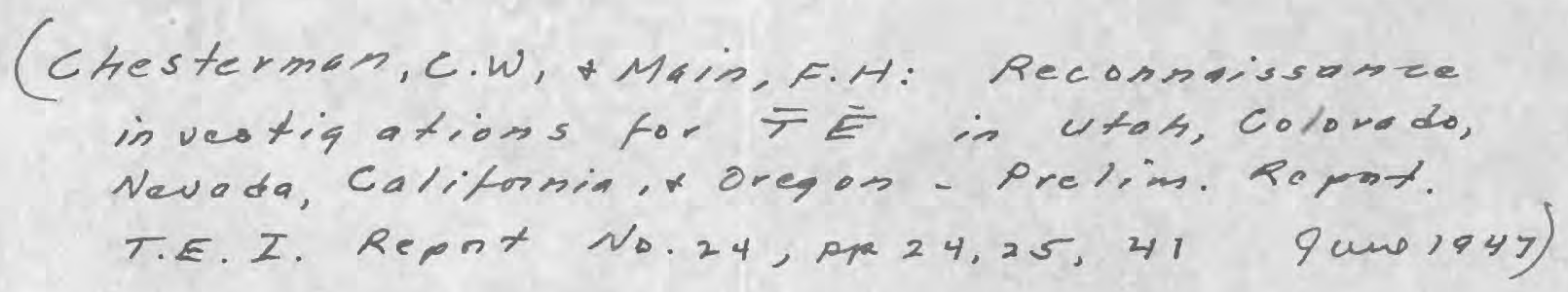


No. 117

UNITED STATES

DEPARTMENT OF THE INTERIOR

GEOLOGICAL SURVEY

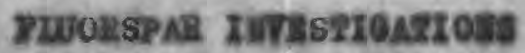 \\ Hoanorealva on the Stasts ulias \\ Deaver Oounty. Utah \\ D.C. Cox and A. I. Grasger \\ Q $-N F I D E N T M A$ \\ mon ver or \\ C. C. Covinumerre \\ - ener
}

U, Q, CEOL SURVEY

Ney 19. 1943

On April 23, the atseate alat wae rielted wth J. 0. Plaher also of the

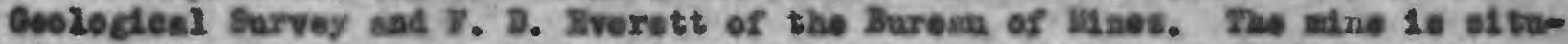

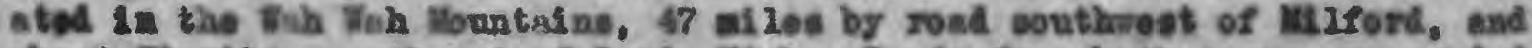

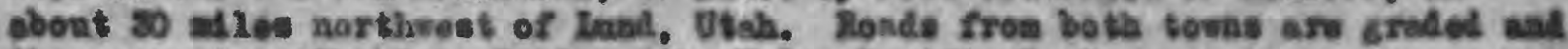

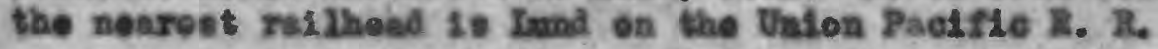

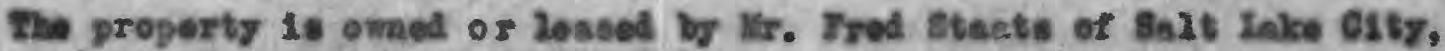
Vtak, end consiats of at 20sat 10 clalms.

It vee leat oporated in 2949 ander contraot by lis. V. Taditups of luzford, vtah. The followikg produetion 21 guree are roported by lif. Steste for tho Stasts or lloarch elaiae and the skoveand mine, all of which are probeb2y the seane property.

Tear

1938

1938

1940

2941

1942
Tone entellurgtenl Plnoropar shlppsd froa stante vine

Staogerd inne
351

$\begin{array}{r}748 \\ 1272 \\ \hline 370\end{array}$

$$
\frac{385}{527} \frac{527}{1370}+101^{5} h^{1938}
$$

The prineipil deposit eonslete of shoote or lentes of rine-ergstalliae to

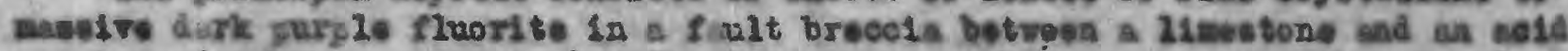
perphyry (probebly extrusive). The limestonsporybyry eontect cea be traed

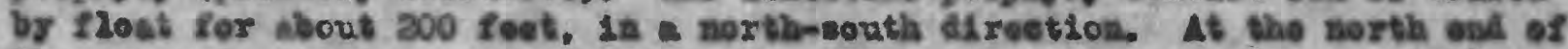

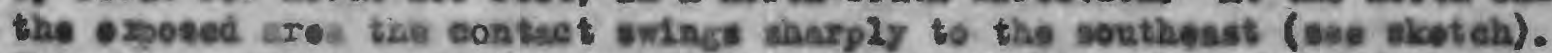
gas sey posibjy be owing to an interaeeting fault. About 300 feet southeest of the ohaxp tare and slong the contact, serorel pdis bev been dus whiein expoee a body of fluori te 30 foat wile (if coptimuous betweed pite) in s white,

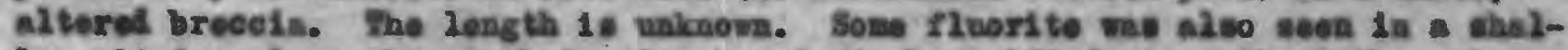
$20 \mathrm{p}$ it dos sloag the north trinding eontact about 260 feot north of the wia ine vorkinge.

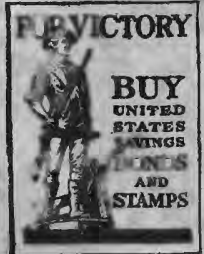


Deatdes the derk easedve rnvorite in the prinolpel ore bedy, there is also a 21t12e green fibreas fluorito, probsbly gouncer than the purple. The

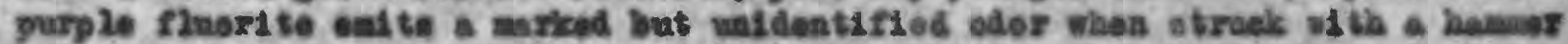

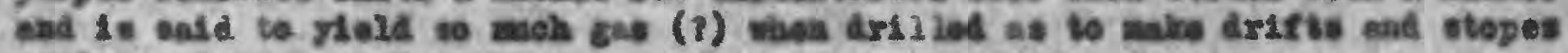
unplesent or oven dangerovs.

From the deseription of ilf. Waddugs, the best ore seens to oecur lergoly

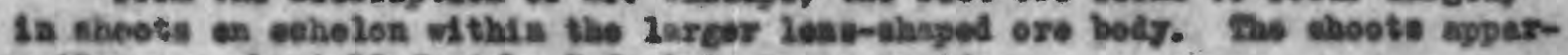
ently wers ebeut 10 roet by toet in esose seetlon.

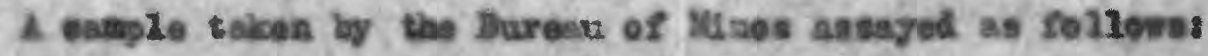

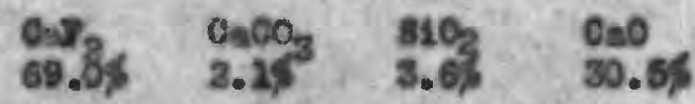

Thse bolly has been wiaed by a comblnetion of open git and underground otoge Eathoda. Zn egen pit extenda to at lenst 25 feet below the havinge level and to a maxiare dapth of about 50 feot sceording to a report by S. D. Hondrieks of the Bureas of ilizes. A sliaft derelopes the aine to the 85-foot level, and ot thas lovel a atope drift axtends oonth for 85 foet.

Ondig to the poer conditios of the muft and Leders, the undercrwand arese vere wasefe and were not visited by the writers.

Do soserves can bo estiasted for the matn ore body at th inspection of the

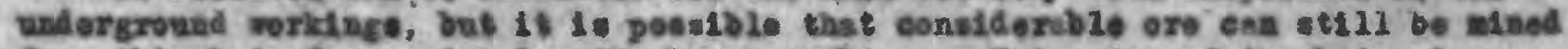

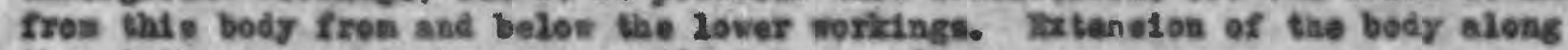
the strike appess to be anrros end of lor grode.

The body to the northeset of the atse is too peorily crpased to estigate tonange. Nile the zrade eppesrs to bo low, a saple froe ono of the pite (wee

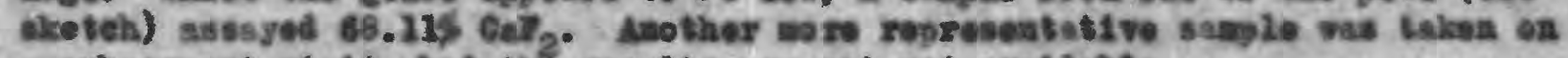

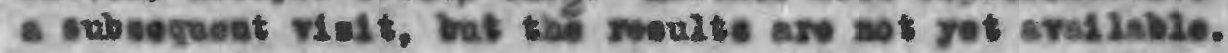

\section{Recumandetiess}

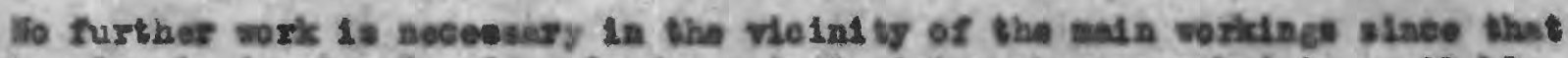
aros 10 alrody doveloped and reedy for cebuel aining when a narket it avalinble.

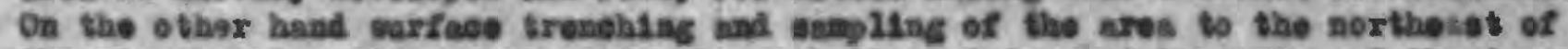

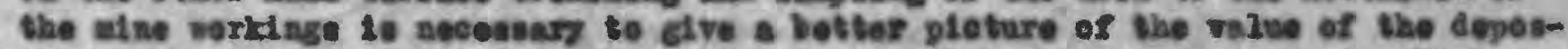

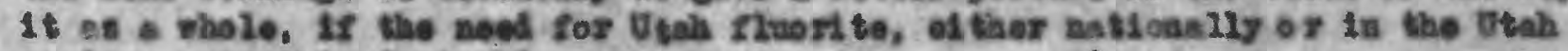
reglon, wais this desireb2e.

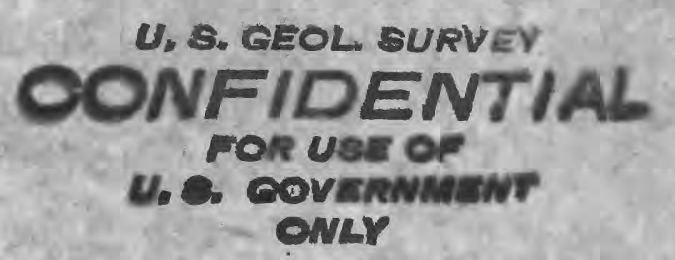




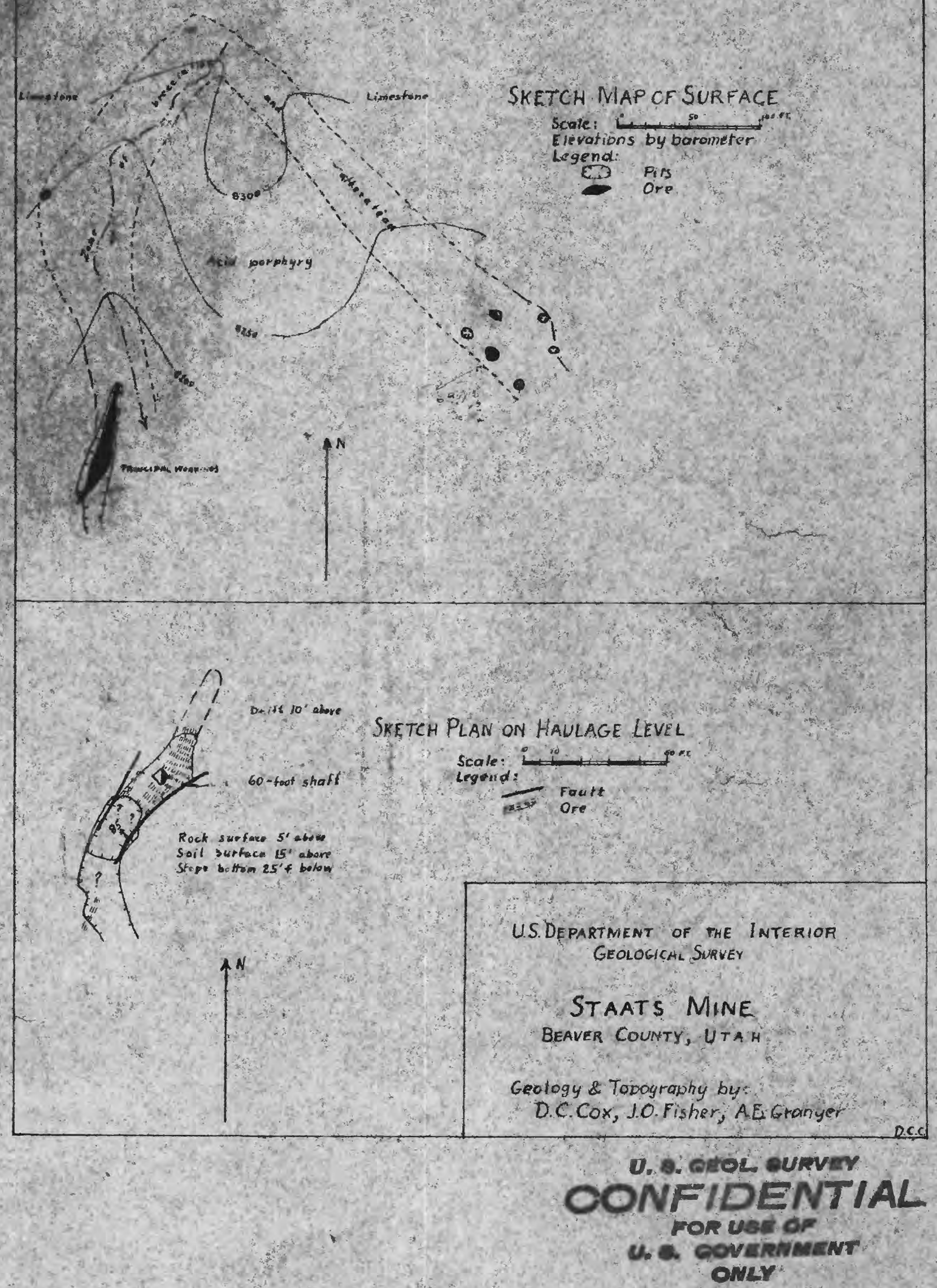




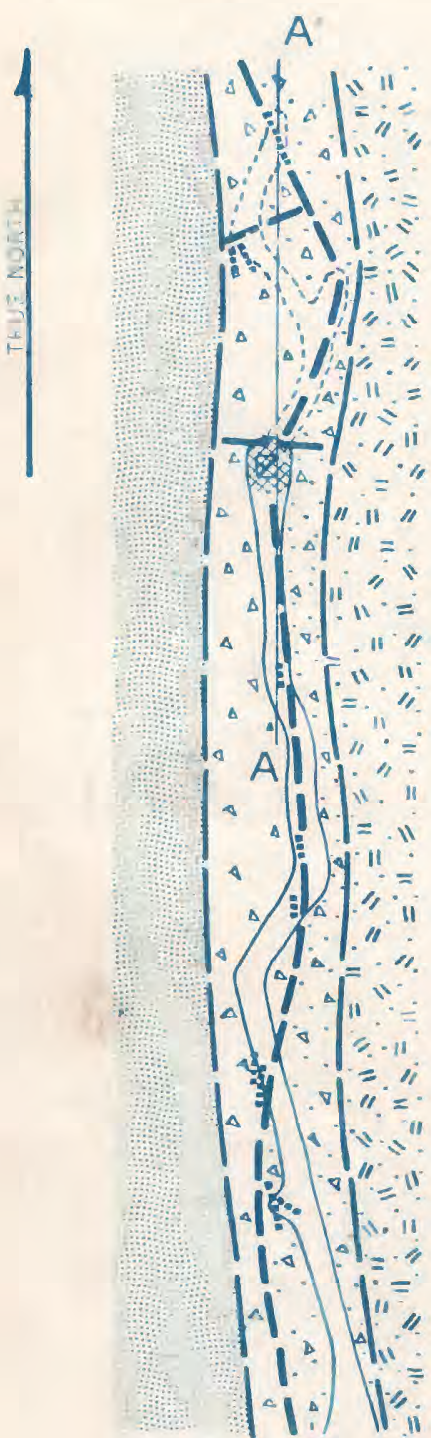

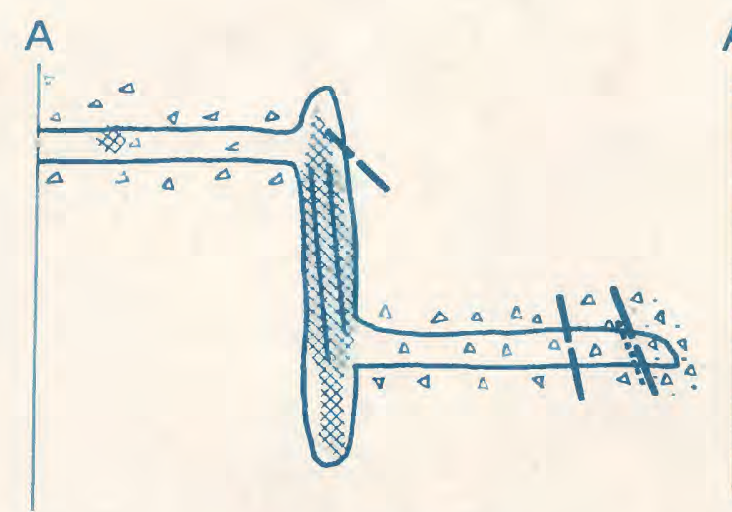

SECTION A-A

Workings in part projected to plane of section

Pace and compass sketch by W. R. Thurston March 1945
EXPLANATION

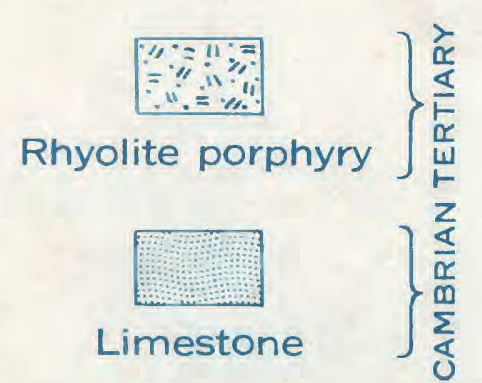

$$
\left[\begin{array}{llll}
\because & \nabla & 0 \\
\hdashline & \nabla & 0
\end{array}\right]
$$

Fault breccia

predominantly

rhyolite porphyry

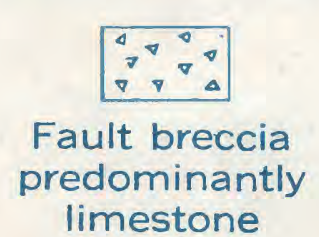

limestone

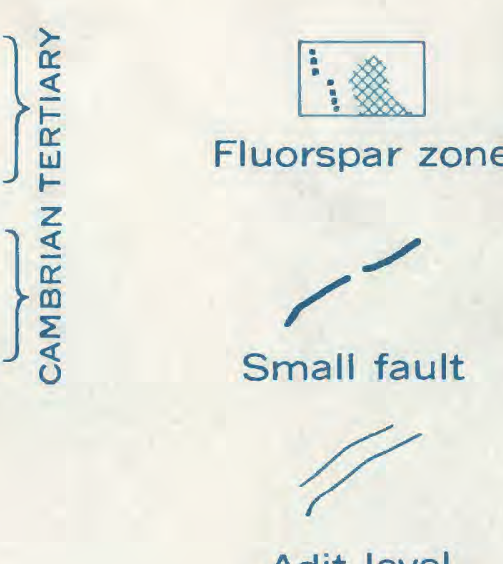

Adit level

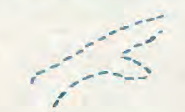

Lower level

$\square$

Winze

Fig. 14. GLOLOGIC SKETCH MAP OF WINZE OPERATION, STAATS MINE, BEAVER COUNTY, U'TAH 
C

0

$\mathbf{P}$

$\mathbf{I}$

Fluorsper deposits of crtah

W. P. THurstor ipp19,20,21.

\section{EXCERPT - UTAAS UTAH}

\section{Nonarch (Staats) claims}

The Monarch claims are located in the Wah Wah Mountains, 47 miles by road southwest of iliford, Utah, and about 35 miles by road northwest of Lund, Utah (see fig. 3). The mine is in T. 29 S., R. 16 W., in what is sometines called the Pine Grove mining district. The claims are owned by Fred Staats of Salt Lake City. Fluorspar was first discovered in the area in about 1935, and some ore has been mined there every year since. The total production up to January 1946 is about 3,500 tons. The claims have been in several hands and called ${ }_{\lambda}$ various names; the Monarch mine, the Skougard mine, and Roberts and Skougard mine, and the Roberts and Staats mine. Recently the area has been roferred to solely by the name of the present operator and is called the Staats area. In April 1943 Cox and Fisher visited the Stagts mine and mapped the relation of the pits and trenches to the up shaft. In March 1945 the writer examined the underground workings and mapped part of them.

The fluorspar deposits occur along the faulted contact of a Tortiary rhyolite porphyry and a Cambrian limestone. The character of eaçh deposit is controlled by local conditions, but the deposits are similar. The silica content of the ore is low and is probably derived from inclusions of rhyolite porphyry; quartz veins are not present in the ore. The lime content is due to the inclusion of limestone fragments. Ho assays are avallable to show the range in $\mathrm{CaF}_{2}$ content of the crude fluorspar. Two grab samples of material from some of the pits northeast of the main shaft contained 50 to 68 percent of $\mathrm{CaF}_{2}$. Assays of carload shipments 
of fuorspar that had been selectively mined and sorted ranged from 80 to 91 percent of $\mathrm{CaF}_{2}$ and averaged in excess of 85 percent of $\mathrm{CaF}_{2}$. The $\mathrm{SiO}_{2}$ and $\mathrm{CaCO}_{3}$ content did not exceed 5 percent, respectively, and averaged about 2 percent of each. The fluorspar occurs in lenticular shoots within larger podlike ore zones. The waste between shoots is composed of brecciated limestone and rhyolite porphyry. Apparently the depth of each shoot is greater than the length: the shoots vary from 2 to 6 feet wide and from 5 to 10 feet long, but are reported to extend more than 25 feet in depth. The shoots are oriented roughly parallel to the irregular contact zone of the limestone and rhyolite porphyry. The contact zone is intricately faulted with variations in strike and dip, and sharp undulations in the trace.

Two separate areas of fluorspar mineralization on the Staats prom perty have been explored. Wost of the prospecting centers around the main deposit at the hoad of the valley. (See fig. 13) A small deposit has been opened about half

Fig. 13. - Sketch map of geology in vicinity of main shaft, Staats mine, Beaver County, Utah.

a mile southeast. (See fig. 14.)

Fig. 14. - Geologic sketch map of winze operation, Staats mine, Beaver County, Utah.

The principal workings at the Staats mine are an 85-foot shaft, an open cut, and an adit. The main deposit was first explored by an open cut. A shaft was sunk at about the center of the open cut, and stopes were driven at various legels beneath the cut. At the 85-foot 
level a drift extends 65 foet southward. About 400 feet southeast of the shaft an adit exposed several pockats of fluorspar along a faulted segment of the contact between the rhyolite porphyry and limestone. (See fig. 13.) Because of caving ground only a small part of the shaftworkings was accessible for examination. Apparently enough fluorspar remains in the vicinity of the shaft to both recovering. Within 600 feet to the north northeast, and southeast, several pits and trenches show fluorspar in the contact zone.

To the southeast, about half a mile, an adit leads to winze operation from which 200 tons of ore was mined in 1944. (See fig. 14.) The ore in the winze formed a shoot 10 feet long, 6 feet wide, and about 55 feet high. 